\title{
Analisis Kesulitan Siswa dalam Memecahkan Masalah Sistem Persamaan Linear Dua Variabel (SPLDV) Ditinjau dari Kesadaran Metakognisi
}

\author{
Rezki Hidayanti ${ }^{1, \text { a) }}$, Nurdin ${ }^{1}$, dan Fajar $^{1}$ \\ ${ }^{1}$ Jurusan Matematika, Fakultas MIPA, Universitas Negeri Makassar \\ ${ }^{\text {a) }}$ reskihidayanti509@gmail.com
}

\begin{abstract}
Abstrak. Penelitian ini bertujuan untuk mengetahui deskripsi kesulitan siswa dalam memecahkan masalah sistem persamaan linear dua variabel ditinjau dari kesadaran metakognisi serta fakto-faktor yang mempengaruhi kesulitan siswa dalam memecahkan masalah Sistem Persamaan Linear Dua Variabel (SPLDV). Penelitian ini adalah penelitian kualitatif menggunakan pendekatan deskriptif. Pengambilan subjek dilakukan dengan memberikan angket kesadaran metakognisi kepada siswa kelas IX yang kemudian dari hasil tersebut dipilih secara purposive 3 subjek. Instrumen yang digunakan adalah angket Metacognitive Awareness Inventory (MAI) yang dikembagkan oleh Scraw \& Dennison, tes diagnostik kesulitan pemecahan masalah sistem persamaan linear dua variabel yang dan pedoman wawancara. Indikator kesulitan pemecahan masalah yaitu kesulitan memahami masalah, kesulitan memikirkan rencana, kesulitan melaksanakan rencana dan kesulitan meninjau kembali. Hasil penelitian menunjukkan: 1) Subjek dengan kesadaran metakognisi tinggi kesulitan dalam memahami masalah pada soal cerita. 2) Subjek dengan kesadaran metakognisi sedang kesulitan dalam memikirkan rencana, kesulitan melaksanakan rencana dan kesulitan meninjau kembali. 3)Subjek dengan kesadaran metakognisi rendah mengalami paling banyak kesulitan dalam memecahkan masalah. Subjek mengalami empat jenis kesulitan yaitu kesulitan memahami masalah, kesulitan memikirkan rencana, kesulitan melaksanakan rencana dan kesulitan meninjau kembali
\end{abstract}

Kata kunci: Kesulitan, Sistem Persamaan Linear Dua Variabel, Kesadaran Metakognisi.

\begin{abstract}
This research aims to know description of students' difficulties in solving problem of linear equation system with two variable viewed from metacognition awareness and factors that cause students' difficulties in solving problem of linear equation system with two variable. The type of research is qualitative research with descriptive approach. Retrieval of subject perfomed by providing metacognition awareness questionnaire to students class IX and from result of metacognition awareness questionnaire selected purposively three subjects. Insrument in this research is questionnaire of Metacognitive Awareness Inventory (MAI) developed by Scraw \& Dennison, diagnostic tes of difficulties in solving problem of linear equation system with two variable and interview guidelines. Indicathors of difficulties in solving problem namely understanding the problem, devising a plan, carrying out the plan, and looking back. Result of research show: 1)subject with high metacognition awareness difficulties in understanding the story problem. 2) Subject with moderate metacognition awareness difficulties in devising a plan, difficulties in carrying out the plan, and difficulties in looking back. 3)subject with low metacognition awareness experience most difficulty in solving problem. Subject difficulties in understanding the problem, difficulties in devising a plan, difficulties in carrying out the plan, and difficulties in looking back.
\end{abstract}

Keywords: Difficulties, Linear Equation System With Two Variable, Metacognition Awareness. 


\section{PENDAHULUAN}

Pemecahan masalah merupakan bagian penting dalam menyelesaikan suatu masalah terutama pada pembelajaran matematika. Wardani (2017) menyatakan bahwa pemecahan masalah merupakan bagian kurikulum matematika yang sangat penting karena dalam proses pembelajarannya maupun penyelesaiannya, siswa dimungkinkan memperoleh pengalaman menggunakan pengetahuan serta keterampilan yang sudah dimiliki untuk diterapkan pada pemecahan masalah atau soal yang bersifat non rutin. Sehingga pada pembelajaran matematika disekolah, guru menjadikan kegiatan pemecahan masalah sebagai bagian penting yang mesti dilaksanakan. Subarinah (2013) menyatakan bahwa pemecahan masalah merupakan salah satu komponen dalam tujuan pembelajaran matematika yang tertuang dalam standar nasional pendidikan di Indonesia. Sehingga kegiatan pemecahan masalah oleh siswa dalam pembelajaran matematika sangat penting. Namun, dalam pemecahan masalah terkadang siswa mendapatkan hambatan-hambatan.

Kesulitan siswa dalam pemecahan masalah merupakan suatu keadaan yang sulit/adanya hambatan-hambatan yang dialami siswa dalam menyelesaikan masalah matematika dengan menggunakan langkah-langkah pemecahan masalah matematika. Hambatan-hambatan tersebut dapat disebabkan oleh faktor kognitif dan faktor non kognitif. Faktor kognitif berkaitan dengan kemampuan otak dalam berpikir. Lestari dan Yudhanegara (2015) menyatakan bahwa aspekaspek kognitif dalam pembelajaran matematika mencakup perilaku-perilaku yang menekankan aspek intelektual seperti kemampuan-kemampuan matematis. Kemampuan matematis ini diantaranya: kemampuan pemahaman konsep, kemampuan berpikir kritis, kemampuan koneksi, pemecahan masalah dan lain-lain. Sedangkan faktor non kognitif berkaitan dengan kemampuan diluar otak dalam berpikir. Terdapat dua faktor yang mempengaruhi proses pembelajaran matematika siswa yaitu faktor afektif dan faktor metakognisi.

Masalah matematika tidak terlepas dengan kehidupan sehari - hari, terutama pada materi Sistem Persamaan Linear Dua Variabel (SPLDV). Masalah pada materi tersebut berupa soal non rutin dalam bentuk soal cerita yang berkaitan dengan kehidupan sehari-hari. Namun demikian, berdasarkan hasil penelitian yang dilakukan oleh Novitasari (2016) dinyatakan bahwa masih banyak siswa yang mengalami kesulitan dalam memecahkan masalah matematika yang berkaitan dengan penerapan materi sistem persamaan linear dua variabel dalam kehidupan sehari-hari.

Dalam memecahkan masalah matematika dibutuhkan proses aktivitas kognisi yang terstruktur dan terkendali dengan baik. Siswa yang mampu mengelola kegiatan kognisinya dengan baik memungkinkan dapat menangani tugas dan menyelesaikan masalah dengan baik pula, Santrock (2007) menyebutnya sebagai metakognisi. Metakognisi didefinisikan sebagai pemikiran tentang pemikiran (thinking about thinking) atau pengetahuan seseorang tentang proses berpikirnya. Sudia (2015) menyatakan bahwa metakognisi merujuk kepada cara untuk meningkatkan kesadaran mengenai proses berpikir dan belajar yang dilakukan.

Oleh karena itu, penelitian ini membahas tentang kesulitan siswa dalam memecahkan masalah Sistem Persamaan Linear Dua Variabel (SPLDV) ditinjau dari kesadaran metakognisi. Hal ini penting, karena apabila siswa tidak terbiasa mengelola kegiatan kognisinya dengan baik akan menimbulkan kesulitan dalam menyelesaikan masalah yang diberikan. Sehingga perlu dilakukan suatu penelitian agar kesulitan serta faktor-faktor penyebab kesulitan pemecahan masalah matematika siswa segera diatasi dan tidak terulang dikemudian hari.

Metakognisi mempunyai peranan penting dalam pemecahan masalah matematika. Hal tersebut didukung oleh penelitian yang dilakukan oleh Wahyuddin (2016) yang menyatakan bahwa metakognisi berpengaruh signifikan positif terhadap kemampuan pemecahan masalah siswa. Melalui pengembangan kesadaran metakognisi, siswa diharapkan akan terbiasa untuk selalu memonitor, mengontrol dan mengevaluasi apa yang telah dilakukannya. Bahkan seseorang perlu mengelola pikirannya dengan baik dengan memanfaatkan pengetahuan yang sudah dimiliki, 
mengontrol dan merefleksi proses dan hasil berpikirnya sendiri yang dapat membantunya dalam memecahkan suatu masalah. Kesadaran akan proses berpikir siswa ini disebut sebagai kesadaran metakognisi.

\section{KAJIAN PUSTAKA}

\section{Pemecahan Masalah Matematika}

Masalah matematika merupakan salah satu yang bersifat intelektual, karena untuk dapat memecahkannya diperlukan pelibatan kemampuan intelektual yang dimiliki seseorang. Masalah matematika yang diberikan kepada siswa di sekolah, dimaksudkan khususnya untuk melatih siswa mematangkan kemampuan intelektualnya dalam memahami, merencanakan, melakukan, dan memperoleh solusi dari setiap masalah yang dihadapinya. Dengan demikian, kebutuhan untuk meningkatkan kemampuan siswa dalam memecahkan masalah dan menjadi pemecah masalah yang sukses menjadi tema penting dalam standar isi kurikulum pendidikan matematika di Indonesia dan standar pendidikan di beberapa Negara (Kirkley, 2003).

Pemecahan masalah merupakan perwujudan dari suatu aktivitas mental yang terdiri dari bermacam-macam keterampilan dan tindakan kognitif yang dimaksudkan untuk mendapatkan solusi yang benar dari masalah (Kirkley, 2003). Pada pembelajaran matematika di sekolah, guru biasanya menjadikan kegiatan pemecahan masalah sebagai bagian penting yang mesti dilaksanakan. Hal tersebut dimaksudkan disamping untuk mengetahui tingkat penguasaan siswa terhadap materi pelajaran, juga untuk melatih siswa agar mampu menerapkan pengetahuan yang dimilikinya kedalam berbagai situasi dan masalah berbeda. Orton (1992) mengemukakan bahwa pemecahan masalah merupakan bentuk belajar paling tinggi. Dengan demikian dapat dikatakan bahwa semua kegiatan mempelajari aturan, teknik, dan isi pelajaran untuk dapat memahami matematika, dimaksudkan agar siswa mampu mecahkan masalah matematika.

\section{Kesulitan Pemecahan Masalah Matematika}

Kesulitan adalah keadaan yang sulit dan sesuatu yang sulit (Depdiknas, 2008). Sedangkan memecahkan masalah matematika merupakan proses menyelesaikan masalah dengan menggunakan langkah-langkah pemecahan masalah matematika, yaitu memahami masalah, menyusun rencana, melaksanakan rencana dan meninjau kembali. Jadi kesulitan pemecahan masalah matematika merupakan suatu keadaan sulit/adanya hambatan-hambatan yang dialami siswa dalam menyelesaikan masalah matematika dengan menggunakan langkah-langkah pemecahan masalah matematika.

Dalam penelitian Novitasari (2016) dikemukakan beberapa kesulitan siswa dalam memecahkan masalah matematika pada materi Sistem Persamaan Linear Dua Variabel (SPLDV) yaitu (1) siswa masih kurang lengkap dalam menuliskan apa yang diketahui dan ditanyakan dari soal, (2) siswa belum bisa membuat model matematika berdasarkan apa yang diketahui dari soal, (3) kebiasaan siswa yang kurang teliti dan salah dalam perhitungan.

Dalam penelitian ini indikator kesulitan siswa dalam memecahkan masalah sistem persamaan linear dua variabel berdasarkan langkah - langkah pemecahan masalah Polya (1973), yakni:

- Kesulitan dalam memahami masalah, yaitu jika: (1) Siswa tidak mampu mengidentifikasi informasi dari soal yang diberikan, (2) Siswa tidak mampu menuliskan apa yang diketahui dan ditanyakan.

- Kesulitan dalam menyusun rencana, yaitu jika: (1) Siswa tidak mampu membuat model matematika, (2) Siswa tidak mampu menentukan konsep yang sesuai dengan masalah, (3) Siswa tidak mampu memilih strategi penyelesaian yang sesuai dengan masalah. 
- Kesulitan dalam melaksanakan rencana, yaitu jika: (1) siswa tidak mampu menggunakan prinsip, (2) siswa tidak mampu mengoperasikan langkah-langkah penyelesaian.

- Kesulitan dalam meninjau kembali, yaitu jika: (1) siswa tidak mampu memeriksa apakah penyelesaiannya benar, (2) siswa tidak mampu menggunakan langkahlangkah yang sama untuk soal yang berbeda.

\section{Metakognisi}

Metakognisi terdiri dari imbuhan "meta" dan "kognisi". "Meta" merupakan awalan untuk kognisi yang artinya "sesudah" kognisi. Secara harfiah metakognisi diartikan sebagai kognisi tentang kognisi, pengetahuan tentang pengetahuan atau berpikir tentang berpikir. Flavell (1979) mendefinisikan metakognisi sebagai pemikiran tentang pemikiran (thinking about thinking) atau pengetahuan seseorang tentang proses berpikirnya.

Menurut Pai'pinan (2015) metakognisi adalah pengetahuan seseorang tentang proses berpikirnya dan segala sesuatu yang berkaitan dengan proses berpikir tersebut selama aktivitas berpikir berlangsung yang dikendalikan oleh dirinya sendiri. Sedangkan menurut Sudia (2015) metakognisi sangat membantu seseorang dalam memecahkan masalah dengan menggunakan segala potensi yang dimilikinya dalam hal merencanakan, memonitoring, dan mengevaluasi proses berpikirnya ketika memecahkan masalah. Jadi metakognisi adalah suatu bentuk kesadaran dalam berpikir untuk mengolah proses berpikirnya sendiri sehingga memunculkan suatu motivasi untuk memperbaiki kerangka berpikirnya dalam menghadapi suatu masalah yang tidak dapat dipecahkan.

Schraw dan Denmison (1994) menyatakan bahwa komponen metakognisi terdiri dari dua yaitu (1) Pengetahuan tentang kognisi dan (2) Regulasi kognisi. Pengetahuan tentang kognisi yaitu kesadaran seseorang tentang apa yang sesungguhnya diketahuinya meliputi pengetahuan mengenai kognisi individu sendiri dan kesuaian antara karakter pribadi sebagai seorang pembelajar dengan situasi belajar. Sedangkan regulasi kognisi yaitu bagaimana seseorang mengatur aktivitas kognisinya secara efektif, mekanisme pengaturan diri yang digunakan oleh individu yang aktif selama memecahkan masalah serta mengatur bagaimana individu belajar.

Pengetahuan tentang kognisi terbagi menjadi 3 sub komponen, (1) Pengetahuan Deklaratif, yaitu pengetahuan tentang diri sendiri sebagai pembelajar serta strategi, keterampilan dan sumber-sumber belajar yang dibutuhkan untuk keperluan belajar, (2) Pengetahuan Prosedural yaitu pengetahuan tentang bagaimana menggunakan apa saja yang telah diketahui dalam declarative knowledge pada aktivitas belajar, (3) Pengetahuan Kondisional yaitu pengetahuan tentang menggunakan suatu prosedur, keterampilan atau strategi, bilamana hal-hal tersebut tidak digunakan, mengapa suatu prosedur berlangsung, dalam kondisi yang bagaimana berlangsungnya.

Regulasi kognisi terbagi menjadi 5 sub komponen, (1) Perencanaan yaitu kemampuan mahasiswa merencanakan aktivitas belajarnya, (2) Strategi mengelola informasi yaitu strategi mengelola informasi berkenaan dengan proses belajar yang dilakukan, (3) Pemantauan terhadap pemahaman yaitu kemampuan dalam memonitor proses belajarnya dan hal-hal yang berhubungan dengan proses tersebut, (3) Strategi perbaikan yaitu kemampuan menggunakan strategi-strategi debugging yaitu strategi yang digunakan untuk membetulkan tindakan-tindakan yang salah dalam belajar, (4) Evaluasi yaitu kemampuan mengevaluasi efektivitas strategi belajar, apakah akan mengubah strategi, menyerah pada keadaan atau mengakhiri kegiatan tersebut.

Komponen-komponen metakognisi tersebut digunakan sebagai dasar dalam penyusunan angket kesadaran metakognisi. 


\section{METODE PENELITIAN}

Penelitian ini menggunakan pendekatan kualitatif. Subjek penelitian ini adalah siswa kelas IX. Penetapan subjek penelitian berdasarkan hasil angket kesadaran metakognisi. Terdapat tiga kategori kesadaran metakognisi, kategori tersebut antara lain:

1. Kategori siswa dengan kesadaran metakognisi tinggi $(91-120)$

2. Kategori siswa dengan kesadaran metakognisi sedang $(61-90)$, dan

3. Kategori siswa dengan kesadaran metakognisi rendah $(30-60)$.

Siswa yang telah dikelompokkan tadi kemudian diambil masing-masing satu untuk mewakili tiap-tiap kategori kemudian diberikan soal tes diagnostik kesulitan pemecahan masalah Sistem Persamaan Linear Dua Variabel (SPLDV). Setelah itu, siswa tersebut diwawancara terkait dengan jawaban yang sudah mereka tuliskan dan menganalisis kesulitan yang mereka alami.

Teknik pengumpulan data dalam penelitian ini meliputi: (1) Pemberian angket kesadaran metakognisi, (2) Tes diagnostik kesulitan pemecahan masalah Sistem Persamaan Linear Dua Variabel (SPLDV), dan (3) Wawancara. Angket kesadaran metakognisi diberikan untuk mengetahui kategori kesadaran metakognisi siswa guna untuk mengambil subjek penelitian yang kemudian akan diberikan soal tes diagnostik kesulitan pemecahan masalah sistem persamaan linear dua variabel. Sedangkan soal tes diagnostik kesulitan pemecahan masalah sistem persamaan linear dua variabel yang dimaksud dalam penelitian ini adalah tes tertulis dalam bentuk uraian. Tes ini bertujuan untuk mengungkap kesulitan-kesulitan siswa dalam memecahkan masalah Sistem Persamaan Linear Dua Variabel (SPLDV). Setelah menyelesaikan soal pada tes tersebut, dilakukan wawancara sebagai alat triangulasi jawaban yang ditulis oleh subjek penelitian untuk mempelajari dan menelusuri kesulitan subjek dalam menyelesaikan soal yang diberikan.

Intrumen yang digunakan telah divalidasi oleh 2 orang validator. Keabsahan data dilakukan dengan triangulasi teknik yaitu membandingkan data yang diperoleh dari tes diagnostik kesulitan pemecahan masalah Sistem Persamaan Linear Dua Variabel (SPLDV) dengan data yang diperoleh dari wawancara.

Analisis data dalam penelitian ini meliputi: (1) Analisis data hasil angket kesadaran metakognisi, (2) Analisis hasil tes diagnostik kesulitan pemecahan masalah sistem persamaan linear dua variabel, dan (3) Analisis wawancara yang terdiri dari tiga langkah berdasarkan Miles, Huberman, \&Saldana (2014), yaitu data condensation, data display, dan conclusion drawing.

\section{HASIL DAN PEMBAHASAN}

Rincian masing-masing subjek yang terpilih disajikan dalam Tabel 1.

TABEL 1. Penetapan Subjek Penelitian

\begin{tabular}{cccc}
\hline No & Kode Subjek & Kategori & $\begin{array}{c}\text { Skor } \\
\text { Angket }\end{array}$ \\
\hline 1 & S1 & Tinggi & 91 \\
\hline 2 & S2 & Sedang & 83 \\
\hline 3 & S3 & Rendah & 54 \\
\hline
\end{tabular}

\section{Deskripsi Kesulitan Subjek Pertama (Kesadaran Metakognisi Tinggi) Soal Pertama}

Pada Gambar 1 terlihat bahwa subjek menyelesaikan soal pertama dengan benar serta menggunakan langkah-langkah penyelesaian yang sistematis. Sehingga dapat disimpulkan bahwa subjek melibatkan metakognisi dalam proses penyelesaian masalah tersebut. 
Hal ini didukung oleh pendapat Anggo (2011) yang menyatakan bahwa siswa dengan kesadaran metakognisi yang baik cenderung dapat memecahkan masalah yang dihadapinya dengan baik dengan pengerahan kesadaran dan pengaturang berpikir yang dilakukannya. Hal tersebut mengindikasikan bahwa metakognisi berperan penting dalam proses pemecahan masalah.

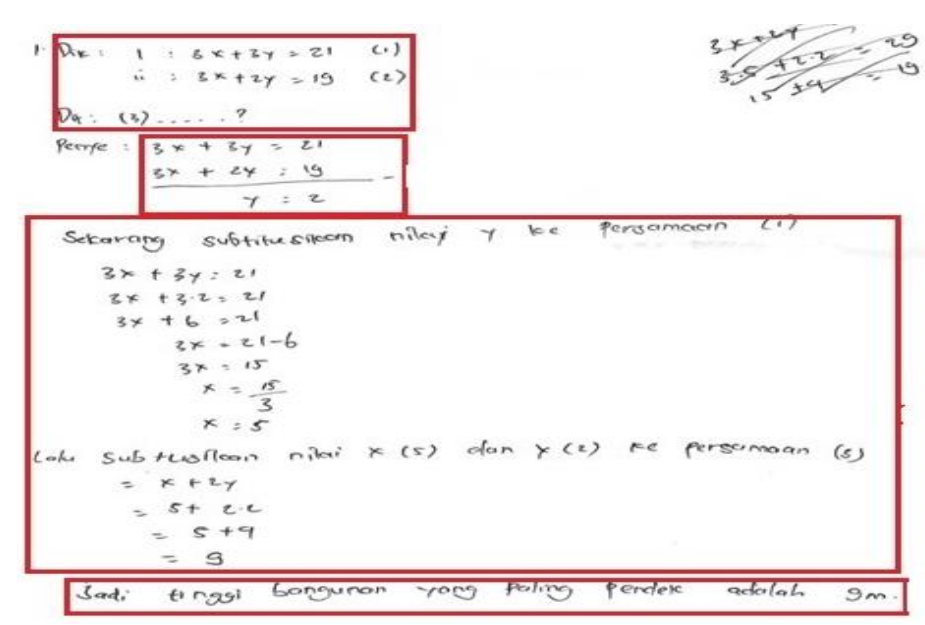

GAMBAR 1. Paparan hasil tes soal pertama subjek kesadaran metakognisi tinggi (MTS)

\section{Deskripsi Kesulitan Subjek Pertama (Kesadaran Metakognisi Tinggi) Soal Kedua}

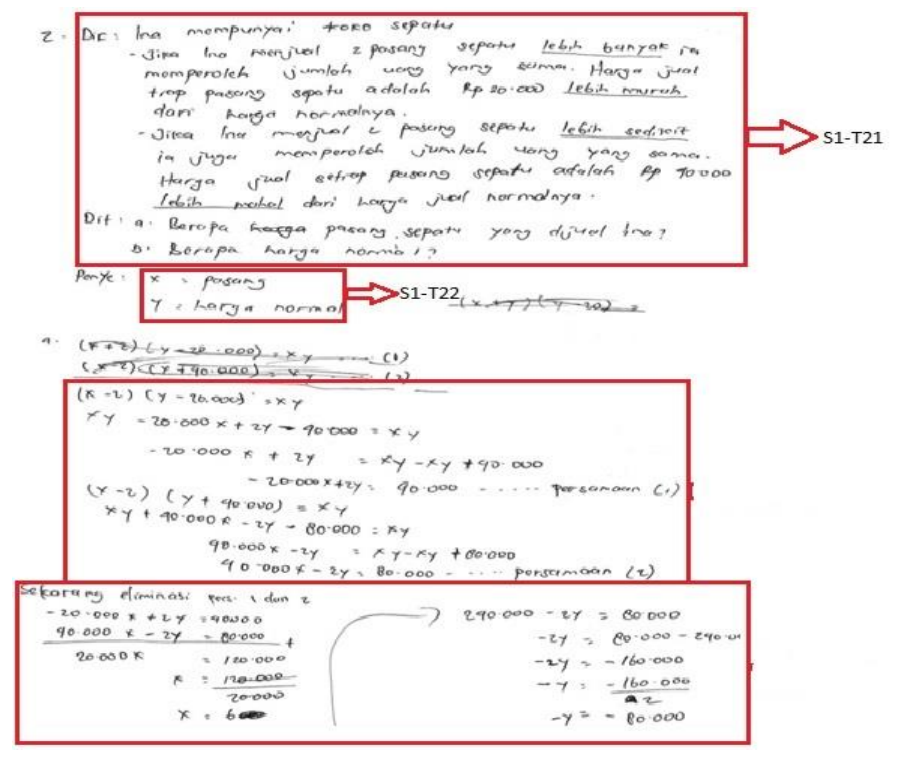

GAMBAR 2. Paparan hasil tes soal kedua subjek kesadaran metakognisi tinggi (MTS)

Pada Gambar 2 terlihat bahwa subjek telah menuliskan diketahui dan ditanyakan pada soal (S1T21). Subjek juga telah memisalkan beberapa informasi dalam bentuk simbol (S1-T22). Serta menyelesaikan soal dengan benar. Namun setelah dikonfirmasi melalui wawancara, ternyata subjek mengalami beberapa hambatan dalam menyelesaikan soal tersebut. 


\section{TRANSKRIP 1}

$P \quad: \quad$ Oke dek. Sekarang perhatikan lagi soal nomor 2. Bagaiaman menurut adik soal nomor 2 ?

S1-W21 : Awalnya bingungka kak kukira ini bukan masalah SPLDV jadi nda mengertika kak tapi gampangji ternyata (sambil tersenyum).

$P \quad:$ Apa ide ta setelah dibaca ini soal ?

S1-W23 : hmm. Awalnya kak tidak ku mengerti sekali ini soalta, tapi setelah kubaca berulang-ulang bisama paham sedikit kak.

$P \quad: \quad$ Apa yang harus dimisalkan dengan menggunakan simbol?

S1-W24 : Ini kak saya toh misalkan $x$ itu banyaknya sepatu (berpasangan) dan y itu harga kak. Jadi beripikirma lagi kalau mauki tau keuntungan yang na dapatkan harus dikali harga dengan berapa pasang sepatu yang terjual itumi $x$ dikali $y$.

Transkrip 1 menunjukkan bahwa subjek membaca soal secara berulang-ulang untuk dapat mengidentifikasi informasi yang dibutuhkan untuk mendapatkan harga jual normal sepatu dan jumlah yang harus tejual (S1-W23, S1-W24). Subjek juga tidak menyadari bahwa masalah pada soal tersebut adalah masalah sistem persamaan linear dua variabel (S1-W21). Sehingga dapat dikatakan bahwa subjek tidak melibatkan metakognisi dalam memahami masalah pada soal tersebut.

\section{TRANSKRIP 2}

$P \quad: \quad$ Kenapa disini ada kuliat $(x+2)(y-20000)=x y$ dan $(x-2)(y+$ $40000)=x y$ langsung dieliminasi $?$

S1-W211 : Awalnya kukira bentuk spldv ji itu kak jadi langsungji ku eliminasi tapi tidak pernah kudapat jawabannya. Jadi kucobami lagi ku kalikan satu satu dan ternyata baruka dapat bentuk spldv nya kak (sambil tersenyum).

Pada Transkrip 2 menunjukkan bahwa awalnya subjek tidak menyadari bahwa $(x+2)(y-$ $20000)=x y$ dan $(x-2)(y+40000)=x y$ bukan bentuk persamaan linear dua variabel. Namun karena proses eliminasi yang dilakukan tidak pernah berhasil maka subjek akhirnya menyadari bahwa $(x+2)(y-20000)=x y$ dan $(x-2)(y+40000)=x y$ bukan bentuk persamaan linear dua variabel, sehingga subjek langsung mengoperasikan bentuk perkalian aljabar terebut dan akhinya subjek mendapatkan model $-20000 x+2 y=40000$ dan $40000 x-2 y=80000$ (S1-W211). Sehingga dapat dikatakan bahwa subjek tidak melibatkan metakognisi dalam memikirkan rencana penyelesaian masalah tersebut.

Jadi, dalam menyelesaikan soal tersebut subjek kesulitan dalam memahami masalah dan kesulitan dalam memikirkan rencana.

\section{Deskripsi Kesulitan Subjek Kedua (Kesadaran Metakognisi Sedang) Soal Pertama}

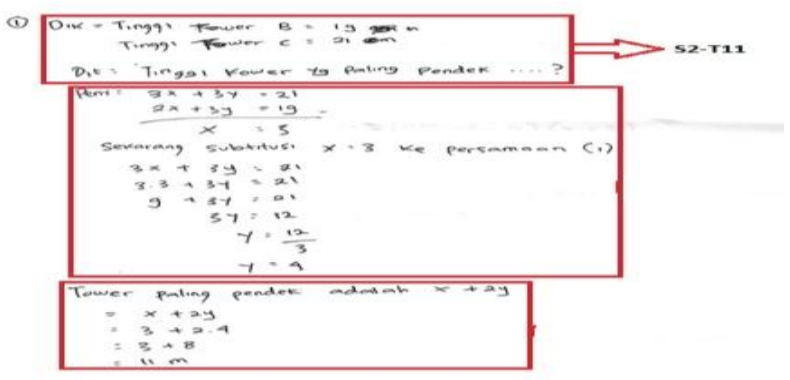

GAMBAR 3. Paparan hasil tes soal pertama subjek kesadaran metakognisi sedang (RH) 
Pada Gambar 3 terlihat bahwa subjek telah menuliskan diketahui dan ditanyakan pada soal (S2T11). Subjek juga menyelesaikan soal tersebut dengan menggunakan langkah-langkah yang sistematis. Namun setelah dikonfirmasi melalui wawancara, ternyata subjek mengalami beberapa hambatan dalam menyelesaikan soal tersebut.

\section{TRANSKRIP 3}

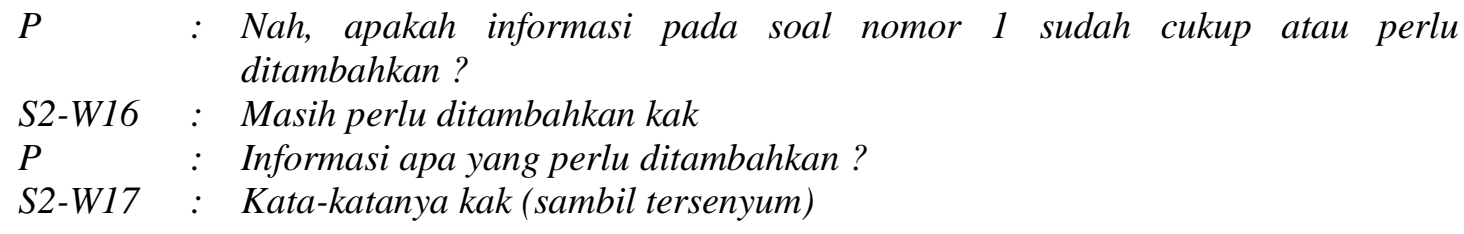

Transkrip 3 menunjukkan bahwa subjek tidak mampu mengidentifikasi informasi yang dibutuhkan untuk mencari tinggi tower yang paling pendek. Subjek tidak menyadari bahwa informasi pada soal sudah cukup untuk menyelesaikan masalah pada soal tersebut (S2-W17). Sehingga dapat dikatakan bahwa subjek tidak melibatkan metakognisi dalam memahami masalah pada soal tersebut.

\section{TRANSKRIP 4}

$\begin{array}{ll}P & : \text { Jadi menurutta benarmi jawabanta ini ? } \\ \text { S2-W120 } & : \text { Benarmi kak. } \\ P & : \text { Nah bagaimana ki bisa pastikan jawabanta ini benar? } \\ \text { S2-W121 } & : \text { Maksudnya kak? } \\ P & : \text { Bagaimana carata mengecek kebenaran jawaban ta? } \\ \text { S2-W122 } & : \text { (terdiam). }\end{array}$

Pada Transkrip 4 menunjukkan bahwa subjek tidak melakukan pengecekan ulang terhadap jawabannya karena subjek tidak menyadari bahwa model matematika yang ditulis salah (S2W120). Subjek juga tidak menginterpretasikan jawaban yang diperoleh.

Jadi, dalam menyelesaikan soal tersebut subjek kesulitan dalam memahami masalah dan kesulitan dalam meninjau kembali.

\section{Deskripsi Kesulitan Subjek Kedua (Kesadaran Metakognisi Sedang) Soal Kedua}

Pada Gambar 4 terlihat bahwa subjek tidak menyelesaikan soal tersebut. Subjek langsung mengeliminasi persamaan $(2+x)(n-20000)=n x$ dan $(2-x)(n+40000)=n x$ padahal bukan bentuk persamaan linear dua variabel (S2-T23). Setelah dikonfirmasi melalui wawancara, ternyata subjek mengalami beberapa hambatan dalam menyelesaikan soal tersebut.

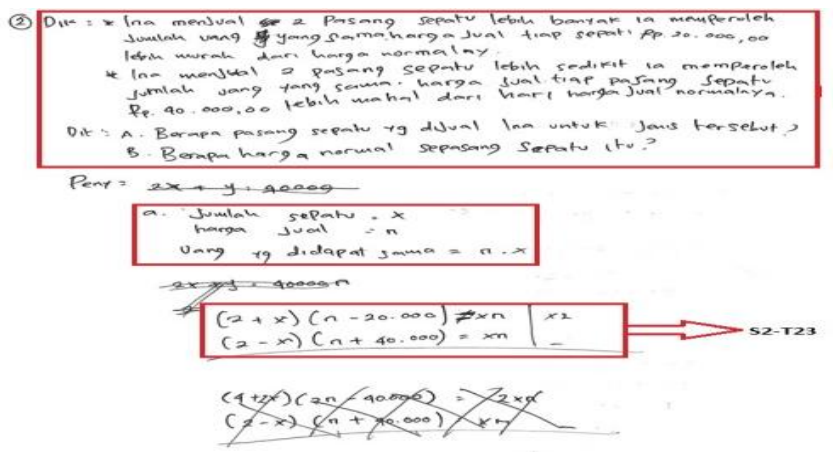

GAMBAR 4. Paparan hasil tes soal kedua subjek kesadaran metakognisi sedang (RH) 
Transkrip 5 menunjukkan bahwa subjek mengalami hambatan dalam membuat model matematika. Subjek tidak melibatkan metakognisi dalam proses penyelesaian masalah terebut karena ketika subjek tidak behasil mengeliminasi 2 persamaan yang didapatkan, subjek masih belum menyadari bahwa bentuk yang diperoleh hanya bentuk perkalian aljabar. Hal tersebut menyebabkan subek tidak memperoleh penyelesaian dari masalah tersebut

\section{TRANSKRIP 5}
$P \quad:$ Setelah didapat seperti ini kira-kira metode apa yang cocok dipakai untuk selesaikan ini soal?

S2-W214 : Kan ini masalah spldv kak, jadi kupikir pastimi itu pakeki eliminasi dan subtitusi.

Jadi, dalam menyelesaikan soal tersebut subjek kesulitan dalam memikirkan rencana, kesulitan dalam melaksanakan rencana, dan kesulitan dalam meninjau kembali.

\section{DESKRIPSI KESULITAN SUBJEK KETIGA (KESADARAN METAKOGNISI RENDAH) SOAL PERTAMA}

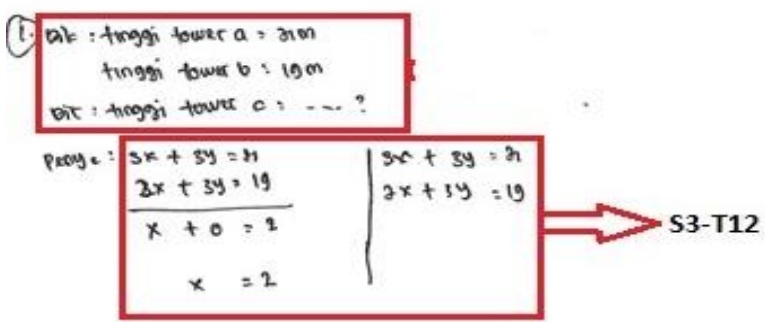

GAMBAR 5. Paparan hasil tes soal pertama subjek kesadaran metakognisi rendah (NH)

Pada Gambar 4 terlihat bahwa subjek tidak menyelesaikan soal tersebut. Subjek tidak berhasil mendapatkan nilai y (S3-T12). Setelah dikonfirmasi melalui wawancara, ternyata subjek mengalami beberapa hambatan dalam menyelesaikan soal tersebut.

\section{TRANSKRIP 6}

\begin{tabular}{|c|c|}
\hline$P$ & hki untuk ubah soal ini ke model matematika? \\
\hline S3-W19 & Susah sekali kak \\
\hline$P$ & $\begin{array}{l}\text { Terus dari manaki dapat model matematika seperti ini (sambil menunjuk } \\
\text { jawabannya) }\end{array}$ \\
\hline S3-W110 & $\begin{array}{l}\text { Sembarangji ku tulis itu kak. Tapi ku liat ki dari bangunnya kak, karena ada } \\
\text { dua bangun yang tersesusun membentuk tower jadi itumi kumisalkan jadi } \\
\text { x dan y kak. }\end{array}$ \\
\hline$P$ & $\begin{array}{l}\text { : Nah, sekarang kan adami model matematika yang kita tulis. Kira - kira metode } \\
\text { apa yang digunakan untuk menyelesaikan soal ini ? }\end{array}$ \\
\hline W111 & (me \\
\hline$P$ & nodel matematika yang kita dapat, kira \\
\hline
\end{tabular}


Pada Transkrip 6 menunjukkan bahwa subjek mengalami hambatan dalam membuat model matematika, karena subjek tidak mengetahui ide sehingga mendapatkan model matematika tersebut (S3-T12, S3-W110). Subjek tidak melibatkan metakognisi dalam menentuka ide/metode penyelesaian yang sesuai dengan model matematika yang didapatkan. Subjek tidak menyadari jika model matematika yang didapatkan adalah bentuk persamaan linear dua variabel sehingga subjek tidak mampu mengaitkan antara model yang sudah didapat dengan konsep/cara yang akan digunakan untuk menyelesaikan masalah tersebut (P, S1-W111).

\section{TRANSKRIP 7}

$P \quad$ : Dari mana kita dapat ini nilai $x=12$ ?kenapa tidak di lanjutnya untuk cari nilai y nya?

S3-W115 : Kukurangkan ji saja kak (menunduk). Kuingat-ingatji sedikit itu kak cara yang pernah diajarkanki tapi sampai situji bisa kuingat kembali. (tersenyum)

Transkrip 7 menunjukkan bahwa subjek tidak melanjutkan penyelesaian model matematika yang telah dibuat. Subjek tidak melibatkan metakognisi karena subjek tidak menyadari bahwa untuk mendapatkan nilai $y$ maka nilai $x$ harus disubtutusikan ke salah satu persamaan (S3W115). Sehingga dapat disimpulkan bahwa subjek tidak mampu menyelesaikan masalah.

Subjek tidak melibatkan metakognisi dari proses merencanakan penyelesaian dan proses penyelesaian masalah sehingga subjek tidak mampu menyelesaikan masalah pada soal tersebut. Metode penyelesaian yang dipilih oleh subjek benar, namun karena subjek tidak melibatkan metakognisi dalam proses penyelesaian sehingga subjek tidak mendapatkan hasil penyelesaian. Sehingga dapat disimpulkan bahwa subjek kesulitan dalam meninjau kembali.

Jadi, dalam menyelesaikan soal tersebut subjek kesulitan dalam memikirkan rencana, kesulitan dalam melaksanakan rencana, dan kesulitan dalam meninjau kembali.

\section{Deskripsi Kesulitan Subjek Ketiga (Kesadaran Metakognisi Rendah) Soal Kedua}

Pada Gambar 6 terlihat bahwa subjek menyelesaikan soal tersebut. Subjek tidak dapat mengidentifikasi informasi yang dibutuhkan untuk mendapatkan harga normal sepatu dan jumlah sepatu yang terjual. Subjek tidak mampu membuat model matematika serta menentukan metode penyelesaian yang sesuai dengan masalah. Sehingga subjek hanya mengoperasikan sembarang bilangan (S3-T22, S3-T23). Subjek tidak mengecek kembali jawabannya karena tidak memperoleh hasil penyelesaian.

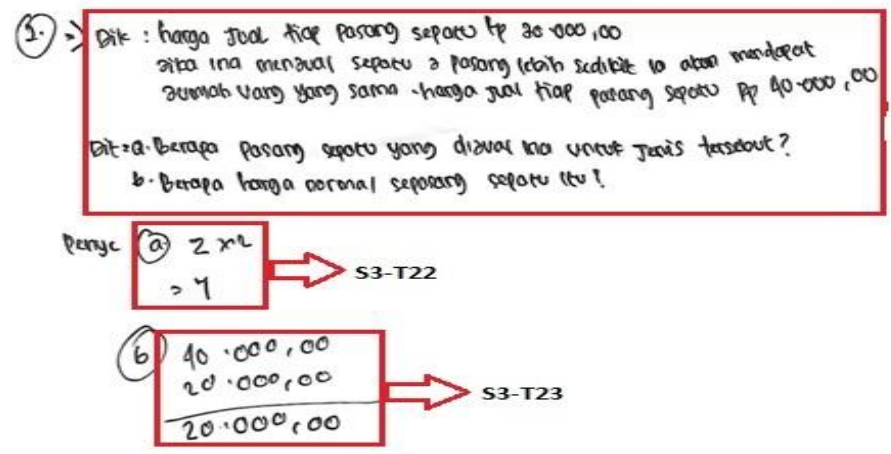

GAMBAR 6. Paparan hasil tes soal kedua subjek kesadaran metakognisi rendah (NH) 
Jadi, dalam menyelesaikan soal tersebut subjek kesulitan dalam memahami masalah, kesulitan dalam memikirkan rencana, kesulitan dalam melaksanakan rencana, dan kesulitan dalam meninjau kembali

Hal ini didukung oleh pendapat Anggo (2011) yang menyatakan bahwa ketika siswa mengalami kesulitan dalam pemecahan masalah, maka kesulitan itu dapat bersumber dari ketidakmampuan memantau secara aktif dan mengatur proses kognitif yang terlibat dalam pemecahan masalah. Oleh karena itu guru seharusnya membiasakan siswa membentuk perencanaan, mengamati langkah-langkahnya saat memeriksa kembali hasil yang telah diperoleh. Hal ini dimaksud agar siswa lebih terbiasa melibatkan metakognisi dalam memecahkan masalah.

Faktor penyebab kesulitan siswa dalam memecahkan masalah Sitem Persamaan Linear Dua Variabel (SPLDV) adalah faktor kognitif dan faktor non kognitif. Faktor kognitif yang mempengaruhi kesulitan pemecahan masalah Sistem Persamaan Linear Dua Variabel (SPLDV) adalah kurangnya penguasaan materi serta konteks soal yang berbeda dengan konteks soal yang dijelaskan guru didepan kelas. Sedangkan faktor non kognitif yang mempengaruhi kesulitan pemecahan masalah Sistem Persamaan Linear Dua Variabel (SPLDV) adalah sikap siswa yang memandang matematika sebagai pelajaran yang begitu sulit, soal-soal dalam matematika beragam, begitu pula cara-cara penyelesaian yang beragam. Sehingga siswa sudah tidak tertarik lagi mengerjakan soal. Dan juga rendahnya kesadaran berpikir siswa dalam mengelola pikirannya dengan baik dengan memanfaatkan pengetahuan yang sudah dimiliki untuk memecahkan suatu masalah matematika menjadi faktor penyebab kesulitan dalam memecahkan masalah matematika.

\section{KESIMPULAN}

1. Subjek dengan kesadaran metakognisi tinggi hanya mengalami kesulitan dalam memecahkan masalah pada soal cerita. Subjek dengan kesadaran metakognisi tinggi mengalami hambatan dalam memahami masalah serta membuat model matematika pada soal cerita.

2. Subjek dengan kesadaran metakognisi sedang mengalami lebih sedikit kesulitan dalam memecahkan masalah dibanding dengan subjek dengan kesadaran metakognisi rendah. Subjek dengan kesadaran metakognisi sedang mengalami kesulitan dalam memikirkan rencana, melaksanakan rencana dan meninjau kembali. Dalam mengerjakan soal cerita subjek dengan kesadaran metakognisi sedang kesulitan dalam mengaitkan informasi pada soal dengan konsep/metode penyelesaian. Sehingga menyebabkan subjek tidak dapat menyelesaikan masalah.

3. Subjek dengan kesadaran metakognisi rendah mengalami paling banyak kesulitan dalam memecahkan masalah. Subjek dengan kesadaran metakognisi rendah mengalam empat kesulitan yaitu kesulitan memahami masalah, kesulitan memikirkan rencana, kesulitan melaksanakan rencana dan kesulitan meninjau kembali. Subjek dengan kesadaran metakognisi rendah kesulitan dalam menganalisis informasi pada soal cerita. Karena subjek kesulitan dalam menganalisi informasi, berakibat tidak ada ide penyelesaian yang subjek pikirkan. Sehingga subjek kesulitan dalam menyelesaikan masalah tersebut.

4. Kesulitan siswa dalam memecahkan masalah disebabkan oleh faktor kognitif dan faktor non kognitif. Faktor kognitif meliputi : (1) kurangnya pengetahuan materi, serta (2) siswa merasa kebingungan saat bentuk soal cerita yang diberikan tidak sesuai dengan bentuk soal cerita yang dijelaskan oleh guru. Faktor non kognitif meliputi (1) sikap, yakni kurangnya ketertarikan siswa dalam menyelesaikan masalah terutama pada soal cerita, serta (2) metakognisi, yakni rendahnya kesadaran berpikir siswa dalam mengelola pikirannya dengan baik dengan memanfaatkan pengetahuan yang sudah dimiliki untuk memecahkan masalah matematika. 


\section{DAFTAR PUSTAKA}

Anggo, M. (2011). Pelibatan Metakognisi dalam Pemecahan Masalah Matematika. Edumatica: Jurnal Pendidikan Matematika, 1(1). 25-32.

Departemen Pendidikan Nasional. (2008). Kamus Besar Bahasa Indonesia Pusat Bahasa Edisi Keempat. Jakarta: PT Gramedia Pustaka Utama.

Flavell, J. H. (1979). Metacognition and Cognitive Monitoring, A New Area of Cognitive Developmental Inquiry. Boston: Allyn and Bacon.

Kirkly, J. (2003). Principle for Teaching Problem Solving. Technical Paper, Plato Learning Inc.

Lestari, K.E., \& Yudhanegara, M.R. (2015). $\quad$ Penelitian Pendidikan Matematika. Bandung: PT. Refika Aditama.

Miles,M.B, Huberman., A.M, \& Saldana, J. (2014). Qualitative Data Analysis, A Methods Sourcebook Edition 3. USA: Sage Publications.

Novitasari, D. (2016). Analisis kesulitan siswa dalam memecahkan masalah matematika materi sistem persamaan linear dua variabel pada siswa kelas VIII semester ganjil SMP Muhammadiyah 4 Sambi Tahun ajaran 2015/2015 (Skripsi). Universitas Muhammadiyah Surakarta, Surakarta.

Orton, A. (1992). Learning Mathematics; Issues, Theory and Classroom Practice Second Edition. Cassell, New York.

Pai'pinan. (2015). Profil Metakognisi Mahasiswa Calon Guru Matematika dalam Menyelesaikan Masalah Terbuka Geometri Ditinjau dari Perbedaan Gender. Jurnal Universitas Cendrawasih.

Polya, G. (1973). How to Solve It: A New Aspect of Mathematical Method. United State of America: University Press, Princeton, New Jersey.

Santrock, J. W. (2011). Educational Psychology $5^{\text {th }}$ Edition. Journal of Educational Psychology, $\operatorname{Vol}(1)$.

Schraw, G., \& Dennison, R. S. (1994). Assesing Metacognitive Awareness. Contemporary educational psychology, 19(4). 460-475.

Subarinah. (2013). Profil berpikir kreatif Siswa dalam Memecahkan Masalah Tipe Investigasi Matematika Ditinjau dari Perbedaan Gender. Jurnal Universitas HaluOleo, 22 (1). 18.

Sudia. (2015). Profil Metakognitif Siswa SMP dalam Memecahkan Masalah Terbuka Ditinjau dari Perbedaan Gender. Jurnal Universitas HaluOleo, 22 (1). 18.

Wahyuddin. (2016). Pengaruh Metakognisi, Motivasi Belajar, dan Kreativitas Belajar Terhadap Kemampuan Pemecahan Masalah Kelas VIII SMP Negeri 2 Sabbangparu Kabupaten Wajo. Jurnal Universitas Muhammadiyah Makassar, 4(1).

Wardani, G. A. K. (2017). Metakognisi Siswa Dalam Memecahkan Masalah Matematika Materi SPLDV Ditinjau dari Perbedaan Gender. Jurnal Mitra Pendidikan, 1(10). 1031-1045. 